\title{
How novel methods can help discover more information about foodborne pathogens
}

\author{
Mansel W Griffiths PhD
}

\begin{abstract}
MW Griffiths. How novel methods can help discover more information about foodborne pathogens. Can J Infect Dis 2000;11(3):142-153.

Considerable emphasis is being placed on quantitative risk assessment modelling as a basis for regulation of trade in food products. However, for models to be accurate, information about the behaviour of potential pathogens in foods needs to be available. The question is how to obtain this knowledge in a simple and cost effective way. One technique that has great potential is the use of reporter bacteria which have been genetically modified to express a phenotype that can be easily monitored, such as light production in luminescent organisms. Bacteria carrying these (lux) genes can easily be detected using simple luminometers or more sophisticated low light imaging equipment.

By monitoring light output from these bacteria over time, it can easily be determined if the organism is growing (resulting in an increase in light emission), is dead (causing a decrease in light production) or is injured (light output remains constant). The use of imaging systems allows the response of bioluminescent bacteria to be studied directly on the food, making the technique even more useful. Applications of bioluminescence are discussed below and include use as reporters of gene expression; biocide efficacy and antibiotic susceptibility; sub-lethal injury; adhesion and biofilm formation; the microbial ecology of foods; pathogenesis; and as biosensors.
\end{abstract}

Key Words: Bioluminescence; Ecology; Foodborne pathogens; Gene expression

\section{Comment des méthodes novatrices peuvent permettre de découvrir plus d'informations sur les pathogènes transmis par la nourriture}

RÉSUMÉ: Un accent considérable est mis sur la modélisation pour l'évaluation du risque quantitatif comme base de réglementation du commerce de produits alimentaires. Cependant, pour que ces modèles soient précis, l'information sur le comportement de pathogènes potentiels dans les aliments doit être disponible. Mais comment peut-on obtenir cette information de façon simple et rentable? Une technique prometteuse est l'utilisation de bactéries-reporters que l'on a modifiées génétiquement pour exprimer un phénotype dont le monitorage est facile, comme la production de lumière dans les organismes luminescents. Il est facile de déceler les bactéries dotées de tels gènes (lux) au moyen de simples luminomètres ou d'un équipement d'imagerie de la lumière faible plus élaboré.

En surveillant la quantité de lumière produite par ces bactéries dans le temps, on peut facilement déterminer si l'organisme croît (ce qui entraîne une plus forte émission de lumière), s'il est mort (ce qui entraîne une diminution de la production de lumière) ou s'il est lésé (la production de lumière reste constante). L'utilisation d'appareils d'imagerie permet d'étudier la bioluminescence des bactéries directement sur la nourriture, ce qui renforce l'utilité de cette technique. Les applications de la bioluminescence sont discutées ci-dessous et comprennent l'utilisation de reporters de l'expression des gènes ; l'efficacité biocide et la sensibilité aux antibiotiques ; la lésion sublétale, l'adhérence et la formation du biofilm ; l'écologie microbienne des aliments ; la pathogenèse ; et les biocapteurs.

\footnotetext{
Presented at the BIOP '99 Symposium, Ryerson Polytechnic University, Toronto, Ontario, February 25, 1999

Department of Food Science, University of Guelph, Guelph, Ontario

Correspondence and reprints: Dr Mansel W Griffiths, Department of Food Science, University of Guelph, Guelph, Ontario N1G 2 W1.

Telephone 519-824-4120 ext 2269, fax 519-824-6631, e-mail mgriffit@uoguelph.ca
} 
B ioluminescence involves the emission of visible light by living organisms through a series of enzyme-catalyzed reactions. Luminescent organisms are found in several ecological niches and comprise species of bacteria, dinoflagellates, fungi, protozoa, sponges, jellyfish, squid, starfish, worms, fish and beetles (1). The biochemistry and genetics of the light reaction have been widely studied, but other potential applications of luminescence are now being explored by scientists in other disciplines. This review will explore the ways in which bioluminescence has been used to gain insights into the behaviour of foodborne pathogens.

The genes responsible for bioluminescence in a wide variety of organisms have been identified and cloned (Table 1), and the molecular biology of bacterial bioluminescence has been described in a series of reviews by Meighen (2-5), and Meighen and Dunlop (6). The relation between the genes and enzymes of the lux operon and the bioluminescence reaction is diagrammatically represented by Figure 1 .

The lux genes have been transferred and expressed in several microorganisms, including foodborne pathogens (Table 2). Luminescent phenotypes have been obtained for Gram-positive and Gram-negative bacteria. However, light output obtained from Gram-positive bacteria is usually about 100 times lower than that from comparable Gram-negative genera, and this is probably the result of poor gene expression (7).

Several reviews on the applications of luminescence have been published (8-19), and many of these applications have relevance to food safety microbiologists.

\section{REPORTER OF GENE EXPRESSION}

The 'reporter' gene concept arose from an inability to easily monitor the products of many genes. A gene with a readily assayed product (the reporter) is fused with the gene of interest so that when the latter is expressed, the product of the reporter gene is synthesized and can be detected. Schauer (20) and Nordeen (21) reviewed the use of luciferase genes for visualizing gene expression, and the former stated that this not only enabled easy detection of transcription or translation, but also allowed localization of the event in cells or organelles. Using photon imaging techniques, O'Kane et al (22) showed that it was possible to detect Rhizobium species carrying the luxAB genes in single cells from infected plants, and these techniques allow gene expression to be visualized in single mammalian cells (23) and bacterial cells (24). The use of the luxAB gene as a molecular reporter is not without limitations, and Blouin et al (25) have cautioned against using the system without appropriate protocol design.

More recently, attention has been focused on the green fluorescent protein gene of Aequorea victoria as a marker for gene expression $(26,27)$. It does not require any substrates or additional co-factors to fluoresce, but the GFP fluorescence phenotype does not indicate the metabolic status of cells. By using a dual $g f p$-luxAB marker system, it is possible to monitor cell number and metabolic activity of specific bacterial populations simultaneously (28).

Expression of toxin and virulence genes: Gene fusions of bioluminescent genes and toxin-producing or virulence
TABLE 1

Cloned luciferases and photoproteins

\begin{tabular}{|c|c|c|}
\hline Organism & Cloned gene & Reference \\
\hline \multicolumn{3}{|l|}{ Bacteria } \\
\hline Photobacterium leiognathi & $\begin{array}{l}\text { Luciferase structural } \\
\text { genes }\end{array}$ & 114 \\
\hline Photobacterium phosphoreum & $\begin{array}{l}\text { Luciferase structural } \\
\text { genes }\end{array}$ & 115 \\
\hline Vibrio fischeri & $\begin{array}{l}\text { Luciferase structural } \\
\text { genes }\end{array}$ & 116 \\
\hline Vibrio harveyi & $\begin{array}{l}\text { Luciferase structural } \\
\text { genes }\end{array}$ & $117-119$ \\
\hline Xenorhabdus luminescens & $\begin{array}{l}\text { Luciferase structural } \\
\text { genes }\end{array}$ & 120 \\
\hline $\begin{array}{l}\text { Unidentified terrestrial } \\
\text { bacterium }\end{array}$ & $\begin{array}{l}\text { Luciferase structural } \\
\text { genes }\end{array}$ & 121 \\
\hline \multicolumn{3}{|l|}{ Beetle } \\
\hline $\begin{array}{l}\text { Luciola cruciata (Japanese } \\
\text { firefly) }\end{array}$ & Luciferase cDNA & 122 \\
\hline Luciola lateralis (firefly) & Luciferase cDNA & 123 \\
\hline $\begin{array}{l}\text { Luciola mingrelica (Eastern } \\
\text { European firefly) }\end{array}$ & Luciferase cDNA & 124 \\
\hline $\begin{array}{l}\text { Photinus pyralis (North } \\
\text { American firefly) }\end{array}$ & Luciferase cDNA & 125 \\
\hline $\begin{array}{l}\text { Pyrophorus plagiophthalamus } \\
\text { (click beetle) }\end{array}$ & Luciferase cDNA & 126 \\
\hline \multicolumn{3}{|l|}{ Other } \\
\hline Aequorea species (jellyfish) & Aequorin cDNA & 127 \\
\hline Vargula hilgendorfii (ostracod) & Luciferase cDNA & 128 \\
\hline Renilla reniformis (sea pansy) & Luciferase cDNA & 129 \\
\hline Clytia gregarium (hydroid) & Clytin cDNA & 130 \\
\hline Obelia longissima (hydroid) & Obelin cDNA & 131 \\
\hline $\begin{array}{l}\text { Anthozoa species } \\
\text { (nonbioluminescent) }\end{array}$ & cDNA & 132 \\
\hline
\end{tabular}

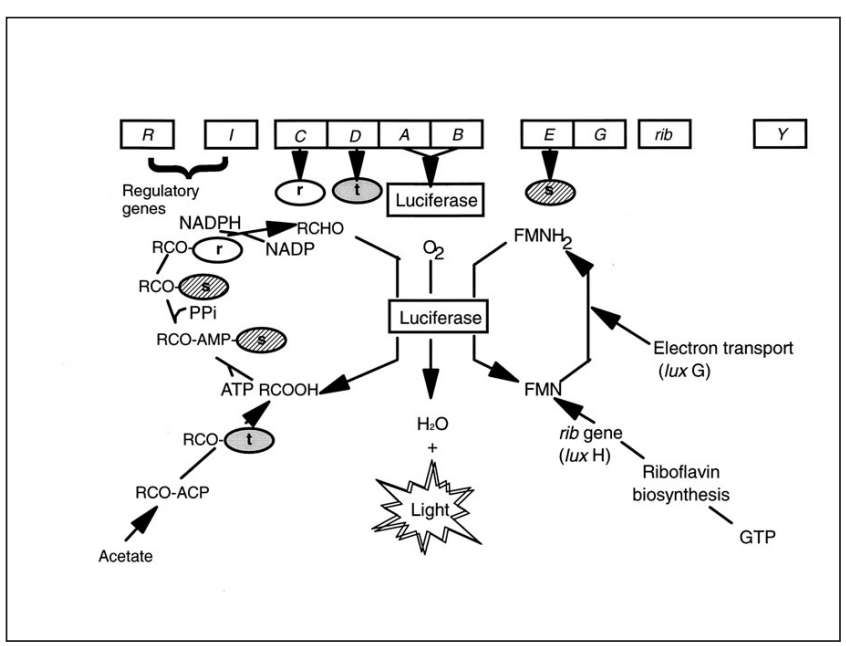

Figure 1) Schematic representation of the genetics and biochemistry of bacterial bioluminescence. ACP Acyl carrier protein; AMP Adenosine monophosphate; ATP Adenosine triphosphate; $\mathrm{H}_{2} \mathrm{O}$ Water; NADP Nicotinamide adenine dinucleotide phosphate; NADPH Reduced nicotinamide adenine dinucleotide phosphate; $\mathrm{O}_{2}$ Oxygen; PPi Inorganic pyrophosphate; $r$ Reductase; $s$ Synthetase; $t$ Transferase 
TABLE 2

Microorganisms engineered to obtain luminescent phenotypes

\begin{tabular}{|c|c|c|c|}
\hline Species & $\begin{array}{c}\text { Transfer } \\
\text { system }\end{array}$ & $\begin{array}{l}\text { Luminescent } \\
\text { genes used }\end{array}$ & Reference \\
\hline \multicolumn{4}{|l|}{ Gram-negative bacteria } \\
\hline Aeromonas salmonicida & $\mathrm{T}$ & Vh luxAB & 133 \\
\hline Agrobacterium radiobacter & $\mathrm{C}$ & Vh luxAB & 134 \\
\hline Agrobacterium rhizogenes & $\mathrm{C}$ & $\begin{array}{l}\text { Vh luxAB, } \\
\text { Vf lux } A B C D E\end{array}$ & 134,135 \\
\hline Agrobacterium tumefaciens & $\mathrm{C}$ & $\begin{array}{c}\text { Vh lux } A B \\
\text { Vf lux } A B C D E\end{array}$ & 134,135 \\
\hline Bradyrhizobium japonicum & $\mathrm{C}$ & Vh luxAB & 22,136 \\
\hline Citrobacter koseri & Tf & Vf lux $A B$ & 46,137 \\
\hline Erwinia amylovora & $\mathrm{C}$ & Vf luxABCDE & 135 \\
\hline Erwinia caratovora & $\mathrm{C}$ & Vf luxABCDE & 135 \\
\hline Escherichia coli & $\mathrm{C}, \mathrm{Tf}, \mathrm{Td}$ & $\begin{array}{l}\text { Vf Vh Pp PI XI } \\
\text { lux, Lm Php luc }\end{array}$ & $3,124,125$ \\
\hline Escherichia coli O157 & $\mathrm{Tf}, \mathrm{Td}$ & $\begin{array}{c}\text { Vf luxAB, } \\
\text { Php luc, } \\
\text { Pl luxCDABE }\end{array}$ & $86,88,91$ \\
\hline Klebsiella aerogenes & Tf & Vf lux $A B$ & 137 \\
\hline Pseudomonas aeruginosa & Tf & Vh luxAB & 138 \\
\hline Pseudomonas fluorescens & $\mathrm{C}$ & Vf luxABCDE & 135 \\
\hline Pseudomonas glumae & $\mathrm{C}$ & Vf luxABCDE & 135 \\
\hline Pseudomonas putida & $\mathrm{C}$ & Vh luxAB & 84,134 \\
\hline Pseudomonas syringae & $\mathrm{C}$ & Vf luxABCDE & 135 \\
\hline Rhizobium meliloti & $\mathrm{C}$ & $\begin{array}{l}\text { Vh lux } A B \\
\text { Vf lux } A B C D E\end{array}$ & 134,135 \\
\hline Rhizobium leguminosarium & $\mathrm{C}$ & Vh luxAB & 134 \\
\hline Salmonella anatum & $\mathrm{Tf}, \mathrm{Td}$ & Vf lux $A B$ & 61 \\
\hline Salmonella enteritidis & $\mathrm{Tf}, \mathrm{Td}$ & Vf lux $A B$ & 61 \\
\hline Salmonella hadar & Tf & PI luxCDABE & 48 \\
\hline Salmonella typhimurium & $\mathrm{Tf}, \mathrm{Td}$ & Vf lux $A B$ & $13,41,46$ \\
\hline Shigella flexneri & Tf & Vf lux $A B$ & 46 \\
\hline Vibrio parahaemolyticus & $\mathrm{Td}$ & Vf luxABCDE & 139 \\
\hline Yersinia enterocolitica & Tf & Vf luxAB, Lm luc & 140 \\
\hline \multicolumn{4}{|l|}{ Gram-positive bacteria } \\
\hline Bacillus megaterium & Tf & Vf lux $A B$ & 36 \\
\hline Bacillus subtilis & Tf & $\begin{array}{c}\text { Vf luxAB, } \\
\text { Vh luxAB, } \\
\text { Php luc, Pyrp luc }\end{array}$ & $\begin{array}{c}36,141 \\
142\end{array}$ \\
\hline Bacillus thuringiensis & Tf & Vf lux $A B$ & 143 \\
\hline Campylobacter jejuni & Tf & $\mathrm{Pl} \operatorname{lux} A B$ & 144 \\
\hline Clostridium perfringens & Tf & Vf lux $A B$ & 145 \\
\hline Lactobacillus casei & Tf & Vf lux $A B$ & 146 \\
\hline Lactococcus lactis & Tf & Vf lux $A B$ & 146,147 \\
\hline $\begin{array}{l}\text { Lactococcus lactis } \\
\text { subspecies diacetylactis }\end{array}$ & Tf & Vf lux $A B$ & 146 \\
\hline Listeria monocytogenes & Tf & Vf lux $A B$ & 68,148 \\
\hline Mycobacterium tuberculosis & $\mathrm{Tf}, \mathrm{Td}$ & Php luc & 109 \\
\hline Mycobacterium smegmatis & $\mathrm{Tf}, \mathrm{Td}$ & Php luc & 110 \\
\hline Staphylococcus aureus & $\mathrm{Tf}, \mathrm{Td}$ & Vf lux $A B$ & 29,105 \\
\hline Streptococcus thermophilus & Tf & Vh luxAB & 149 \\
\hline Streptomyces coelicolor & Tf & Vh luxAB & 20 \\
\hline \multicolumn{4}{|l|}{ Yeast } \\
\hline Saccharomyces cerevisiae & Tf & Vh luxAB & 150 \\
\hline
\end{tabular}

C Conjugation; Lm Luciola mingrelica; Php Photinus pyralis; PI Photobacterium leiognathi; PI Photorhabdus (Xenorhabdus) luminescen; Pp Photobacterium phosphoreum; Pyrp Pyrophorus plagiophthalamus; Tf Transformation; Td Transduction; Vf Vibrio fischeri; Vh Vibrio harveyi

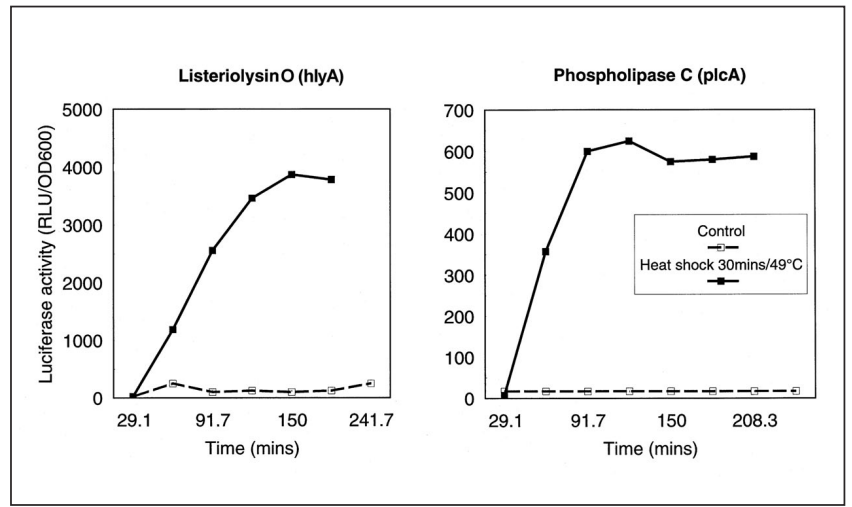

Figure 2) Bioluminescence as a reporter of virulence factor gene expression in Listeria monocytogenes. Data from reference 34

factor-associated genes can be made so that expression of the latter will be accompanied by light emission. Sheehan et al (29) used this approach to study the epidermolytic toxin (eta) gene of Staphylococcus aureus, which encodes a toxin causing the exfoliation of skin in neonates. They fused the promoter region of the eta gene with the Photobacterium (Vibrio) fischeri luxAB gene and found that expression of the eta gene was growth-phase dependent, being more rapidly transcribed during the late exponential to early stationary phase. The eta gene was also shown to be under the control of an accessory gene regulator. Furthermore, the effects of environmental conditions, such as osmotic strength, on the eta promoter could be assessed by this method. This technology provides a unique opportunity to study, in real time and nonintrusively, the control of epidermolytic toxin synthesis during the disease process using in vivo experimental models (16). A luciferase-based reporter system has also been used to study the expression of the toxic shock syndrome toxin-1 (tst) gene of $S$ aureus (30), and the results suggested that a reduction in specific growth rate was the major factor controlling tst expression.

A haemolysin (listeriolysin O) and phospholipase C, encoded by genes designated $h l y A$ and plcA, respectively, have been shown to play a role in the virulence of Listeria monocytogenes $(31,32)$. These genes, along with others located in the virulence chromosomal region, are coordinately regulated by the product of the prfA gene (33). Park et al (34) constructed mutants of $L$ monocytogenes in which the promoter sites of the hlyA and the plcA genes were fused with the $V$ fischeri lux $A B$ gene. They found that light emission was much higher in strains containing an intact copy of $p r f A$, providing confirmation that the activity of these promoters was dependent upon the transcriptional activator, PrfA. They were also able to show that synthesis of listeriolysin $\mathrm{O}$ and phospholipase $\mathrm{C}$ was induced by heat shock (Figure 2), whereas oxidative stress had no effect on the expression of these virulence factors. In addition, the medium composition had a marked effect on the expression of the virulence genes. For example, it has been reported that the $h l y A$ and $p l c A$ genes are repressed in the presence of cellobiose (35).

In the future, this technique will provide valuable information on how food composition and the environment in which 
food is stored affect the pathogenicity of organisms responsible for foodborne illness, as well as shed light on events that occur when the pathogen enters the gastrointestinal tract.

Reporter of germination and sporulation: Luciferase has been used as a marker for gene expression in Bacillus species $(36,37)$. Spores of lux recombinant bacteria do not luminesce until germination occurs, and this provides a valuable tool for the study of gene expression during both germination and sporulation. Another application for bioluminescent constructs of Bacillus megaterium involves the determination of the heat resistance of spores (38), which can be predicted because the level of light output from these mutants is directly proportional to the heat treatment received (39).

Reporter of cellular injury: Because the bacterial luciferase reaction requires a reduced form of flavin mononucleotide, any stimulus that affects the intracellular production of this substrate will result in a change in light output. This makes bioluminescence an effective tool for monitoring sublethal injury and subsequent recovery from the physiological insult $(13,14,40)$. As an example, recovery from cellular injury caused by freezing has been studied using a luxAB recombinant of Salmonella typhimurium (41). Cells of the bacterium $\left(10^{5} / \mathrm{mL}\right.$ in peptone water) were frozen at $-20^{\circ} \mathrm{C}$ and, after thawing, they were compared with a culture of non-frozen cells by measuring bioluminescence and plate count. The data obtained by both methods were equivalent, but the bioluminescence measurements were obtained in real time. Interestingly, freezing brought about a 40-fold reduction in viable cells, whether measured by bioluminescence or by plate count, after a $2 \mathrm{~h}$ recovery period in Luria broth. However, the bioluminescence data indicated that, immediately after thawing, there was only a fivefold difference between control and frozen cultures (14). From these figures, Stewart (14) concluded that $20 \%$ of the $S$ typhimurium population was able to survive the freeze-thaw cycle, with an intracellular biochemistry sufficiently intact to allow immediate light production, but only $2.5 \%$ of the cells were capable of division. In other words, a large proportion of cells could survive freezing with a functional metabolic system but these cells were not viable. Thus, bacteria that are sublethally injured in this manner could continue to produce toxigenic compounds, even though they remain nonculturable. The exact mechanism for induction of this so-called 'viable but nonculturable' (VNC) state is poorly understood, but vital information on the metabolic activity of VNC organisms can be provided by studying bioluminescent phenotypes $(42,43)$. Duncan et al $(44)$ followed the response of Vibrio harveyi and bioluminescent strains of Escherichia coli and Pseudomonas fluorescens to starvation, and found that quantification of luminescence changes enabled measurement of both culturable and VNC cells. Such information may allow the hypothesis of Bloomfield et al (45) to be tested; they suggest that the VNC phenomenon is the result of an imbalance in metabolism set up when stressed cells are suddenly transferred to a nutrient-rich medium. This leads to an almost instantaneous production of superoxide and free radicals which these nonadapted cells cannot detoxify, and, as a consequence, some or all of these cells die.
Ellison et al (41) also reported on the use of bioluminescence to elucidate the mechanism of freeze injury. They found that the rate of freezing affected the survival of $S$ typhimurium. Survival rates in supercooled $\left(-70^{\circ} \mathrm{C}\right)$ cultures were significantly lower than those in cultures frozen to $-20^{\circ} \mathrm{C}$ at the same freezing rate. An osmoregulated proU promoter fused with $\operatorname{lux} A B$ (46) was used to confirm that freeze injury was the result of membrane damage, resulting in leakage and not accumulation of potassium ions (41).

Chen and Griffiths (47) used a luminescent strain of Salmonella enteritidis, with the luxAB genes chromosomally located, to monitor recovery from acid and heat shock. A culture of the luminescent salmonella was subjected to stress and allowed to recover in a nonselective medium at room temperature for $20 \mathrm{~h}$. The cells could recover from exposure to either hydrochloric acid ( $\mathrm{pH} 1.8$ ) or acetic acid ( $\mathrm{pH} 3.9$ ) for 2 mins, and recover from heating at $55^{\circ} \mathrm{C}$ or $65^{\circ} \mathrm{C}$ for 60 mins. This approach was further adapted by Bautista et al (48). In their work, a luminescent strain of Salmonella hadar was constructed and used to inoculate turkey breast meat samples. These were then treated with lactic acid $(4.25 \%, \mathrm{pH} 3.0)$ at $40^{\circ} \mathrm{C}$ for $10 \mathrm{~s}$, before storage at $-12^{\circ} \mathrm{C}, 0^{\circ} \mathrm{C}, 5^{\circ} \mathrm{C}$ and $10^{\circ} \mathrm{C}$. Viability of the salmonella was measured as light emitted from the bacterial cells directly on the turkey breast, and recovery from injury was estimated by monitoring light output after incubation at $22^{\circ} \mathrm{C}$ for $10 \mathrm{~h}$. Unexpectedly, the lowest recovery rate was observed after storage at $5^{\circ} \mathrm{C}$ and the fastest recovery was on turkey breasts that had been stored frozen at $-12^{\circ} \mathrm{C}$. The ability to observe recovery of bacteria from insult directly on foods can provide much more information than studies performed in culture media.

During the early stdationary phase, bacterial cells acquire greater resistance to environmental stressors, such as heat, low $\mathrm{pH}$ and osmotic pressure, due to the induction of specific sets of genes by an RNA polymerase sigma factor (RpoS) encoded by the rpoS gene (49). There are several mechanisms at the transcriptional, post-transcriptional and post-translational levels for regulation of RpoS in E coli and Salmonella species (50). Thus, a reporter of rpoS transcription would not be a reliable indicator of intracellular levels of active RpoS. In some Salmonella serovars, it has been shown that a virulence determinant transcribed by the gene $s p v A$ is under the control of the product (SpvR) of the $s p v R$ gene (51). The $s p v R$ gene is, in turn, under the control of RpoS. With this in mind, Swift and Stewart (52) developed a spv::lux bioluminescence reporter of RpoS activity, and used this reporter to show that events under the control of Rpos could be induced in the presence of a competitive microflora at levels of $10^{6}$ cells or more. Thus, in the presence of high levels of competing cells, salmonella acquired resistance to several environmental stresses (53). Stewart's group also used this reporter to demonstrate that they could monitor Rpos levels in cells in model food systems (54).

Bioluminescence has also provided a novel method for studying stress responses in foods at the molecular level. Lux gene fusions with the promoter sequences of genes involved in stress responses have been constructed in E coli, so that the organism emits light when it is under a stress that triggers transcription of the stress promoter:luxCDABE gene fusion (55-60) 


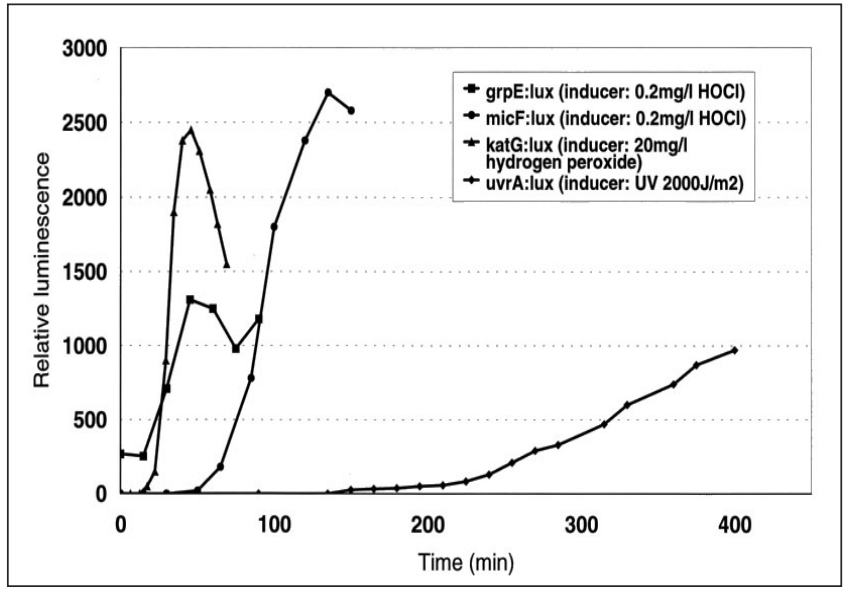

Figure 3) Stress promoter gene::lux gene fusions to report on induction of stress in Escherichia coli. HOCl Hypochlorous acid. Data from references $55,57,60$

(Figure 3). Using these constructs, it has been shown that chlorine triggers an oxidative stress response, inducing activation of both heat shock and soxRS regulons within $1 \mathrm{~s}$ of exposure to free chlorine (57). Mutants of $E$ coli carrying gene fusions of the luxCDABE genes with DNA damage-inducible promoters recA, uvrA and alkA may help in further elucidating the mechanisms involved in DNA repair (60). It is not difficult to envisage how powerful this technique will be when used in conjunction with imaging techniques that allow light emission to be detected directly in foods $(48,61)$ and from single bacterial cells $(24)$.

\section{REPORTER OF BIOCIDE EFFICIENCY AND ANTIBIOTIC SUSCEPTIBILITY}

Bioluminescence can be used to test rapidly the efficacy of sanitizers and disinfectants used in the food industry. Light emission from a lux recombinant organism is dependent on a functional intracellular metabolism, and any substance that interferes with these intracellular processes will result in a decrease in light production. These responses occur very rapidly, usually within 15 mins, giving a real time estimate of the efficiency of the sanitizing or disinfecting procedures $(13,18$, $19,62,63)$. It is possible to produce biosensors consisting of a genetically engineered bioluminescent reporter organism interfaced with an integrated circuit to report on the presence of microbial inhibitors (64). Indeed, bioluminescent bacteria have been used to assess the ability to clean food processing equipment effectively (65).

Walker et al (66) used bioluminescent constructs of $L$ monocytogenes to measure the antilisterial activity of phenol and chlorhexidine diacetate. After determining the time for a $\log _{10}$ reduction in count or light output (D-value) at different biocide concentrations and plotting a double log plot of D-value against biocide concentration, the concentration exponents were calculated from the slope of the best fit line. Similar results were obtained when concentration exponents were assessed using plate count ( 8.3 for phenol and 2.13 for chlorhexidine) or the bioluminescent strains of $L$ monocytogenes $(7.3$ for phenol and 2.63 for chlorhexidine). However, the results were obtained in 60 mins by the latter method. The lux recombi-

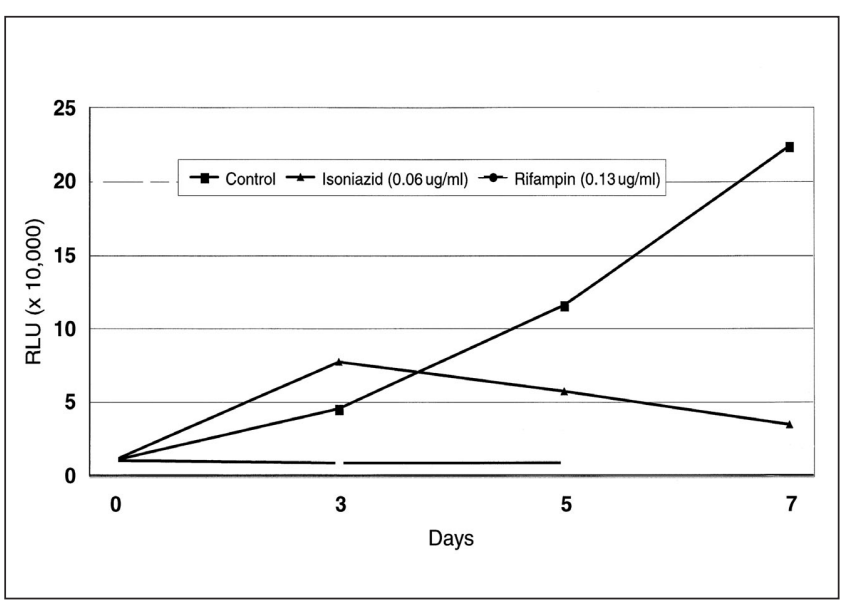

Figure 4) Assay of susceptibility of intracellular Mycobacterium tuberculosis to isoniazid and rifampin using bioluminescence. Data from reference 76

nant $L$ monocytogenes strains were also used to study the efficacy of the disinfectant Virkon (67), as well as other biocides including hypochlorite (68). Bacteria with bioluminescent phenotypes can also be used to measure antimicrobial activity against cells present as a biofilm, as well as the presence of environmental toxicants $(14,18,69,70)$.

Agents that affect the integrity of cell membranes can also be assayed using bioluminescence. The click beetle luciferase gene has been cloned into several microorganisms, such as $E$ coli, Bacillus subtilis and Spodoptera frugiperda. The luciferase enzyme encoded by the gene requires luciferin as a substrate. The diffusion of this substrate through cell membranes is slow at physiological pH and, therefore, a change in membrane permeability is seen as a change of in vivo luminescence of the cells (71). This technique has value for the assay of nisin and other membranolytic biocides and antibiotics.

Bioluminescence can be used to monitor the response of cell-wall deficient (L-forms) of $L$ monocytogenes to biocides (72). These L-forms are difficult to culture, and the use of bioluminescence offers a near real time method for determining viability. L-form colonies required at least three days and as long as 21 days to become visible on agar plates, but they could be detected by bioluminescence after only $8 \mathrm{~h}$ of incubation.

The use of a lux recombinant bacterium for determining antibiotic susceptibilities was first described by Ulitzur and Kuhn (73). Since then, reporter strains of bacteria expressing firefly or bacterial luciferase have been used to evaluate the activities of antibiotics against Mycobacterium tuberculosis and $S$ typhimurium in whole animal studies $(74,75)$ and against mycobacteria sequestered in human macrophages (76) (Figure 4). This technique may also be useful when evaluating the actions of antibiotics against other intracellular pathogens such as $L$ monocytogenes.

\section{REPORTER OF ADHESION AND BIOFILM FORMATION}

The adhesion of bacteria to surfaces has been studied by in vivo bioluminescence (69,77-80). Mittelman and co-workers $(79,81)$ developed an on-line system for monitoring bacterial 
adhesion by a $P$ fluorescens strain containing the $V$ fischeri lux gene operon. Both biofilm and bulk phase biomass could be assayed with a detection limit of $210^{5}$ attached cells $/ \mathrm{cm}^{2}$. Light production was related to biofilm lipid synthesis per unit area. The method has potential for the study of bacterial adhesion to cells during infection and as an indicator of the bactericidal activity of host defence mechanisms (82).

The use of bioluminescence may help us understand the mechanisms of biofilm formation at the molecular level. A bioluminescent reporter plasmid, pUTK50, of alginic acid biosynthesis has been transconjugated into strains of Pseudomonas putida, Pfluorescens and Stenotrophomonas maltophilia (83). When stimuli that increased alginate synthesis were applied to these strains, increased bioluminescence was observed, but exopolysaccharides other than alginate were produced. This suggests that the strains possessed homologous promoter sequences which control the genes necessary for the production of exopolysaccharides in response to environmental stimuli.

Bioluminescence also has application in the study of biofilms in the food industry. Dhir and Dodd (69) studied the resistance of substratum-attached, detached and planktonic cells of $S$ enteritidis phage type 4 to biocides using in vivo bioluminescence. An excellent correlation between bioluminescence and classical plate count data was obtained when attachment profiles, biocide concentration exponents and thermal inactivation (D-values) were compared. There is a clear difference in the susceptibility to biocides of attached cells and those present in biofilms. Following treatment with a nonfoaming acid sanitizer or a liquid hypochlorite sanitizer, bioluminescent $P$ putida cells present as a biofilm on $\mathrm{n}$-buna rubber were able to recover after a $16 \mathrm{~h}$ resuscitation period and grow to levels approaching those of nontreated controls (84). Bioluminescence has also been used to demonstrate that L-forms of $L$ monocytogenes are capable of forming biofilms on stainless steel and other surfaces (85).

Bioluminescence may also be applied in studies on the adhesion of bacteria to food. Siragusa et al (86) used a luminescent strain of $E$ coli 0157:H7 to study adhesion of the organism to beef carcass tissue. They found that retention of the bioluminescent signal was higher on lean fascia-covered tissue than on adipose fascia-covered tissue following a water rinse and that the luminescence was strongly correlated with bacterial counts.

\section{REPORTER OF THE MICROBIAL ECOLOGY OF FOODS}

The use of luminescence-based systems for studying microbial ecology has gained widespread acceptance by environmental microbiologists (87), and these techniques are now being applied to food. As well as providing quantitative information, imaging of luminescent bacterial cells can also provide information on their spatial distribution in a food. Chen et al (61) studied the ability of a lux recombinant of $S$ enteritidis to penetrate the egg shell membrane and to grow in eggs under different storage conditions. This strain of $S$ enteritidis was unable to penetrate the egg shell membrane but was able to grow in the space between the shell and membrane. The lumi-

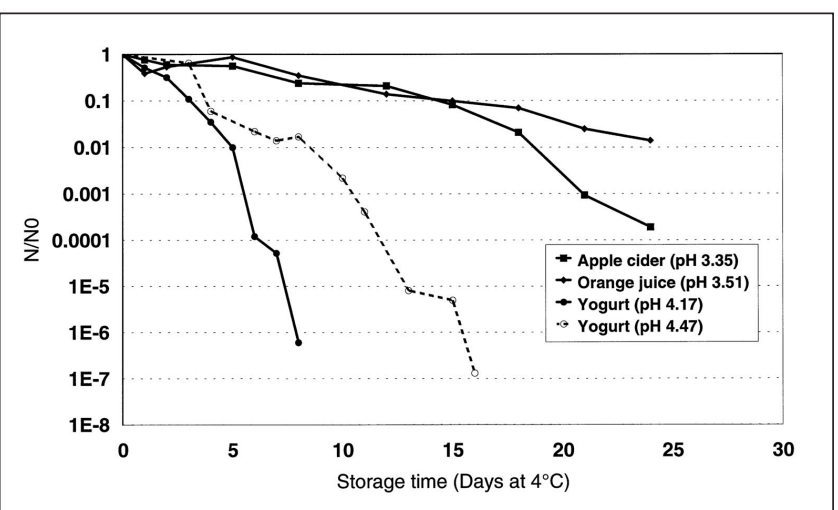

Figure 5) Survival of luminescent phenotypes of Escherichia coli 0157:H7 in apple juice (91), orange juice (91) and yogurt (88), determined by bioluminescence

nescent Salmonella strain could remain metabolically active in eggs after storage at $4^{\circ} \mathrm{C}$ for four weeks (61). The technique is nondestructive, gives real time results and can be carried out directly on the food of interest.

Luminescent and fluorescent strains of $L$ monocytogenes and $E$ coli 0157:H7 have been used to monitor the survival of the organisms in yogurt and cheese $(88,89)$, during a simulated fermented sausage manufacturing process (90), and in apple and orange juice (91) (Figure 5).

These survival studies indicate that bioluminescent reporter microorganisms have great potential as tools for developing quantitative risk assessment models. Already, thermal inactivation models for $S$ typhimurium derived using bioluminescent strains have been shown to be equivalent to models calculated from plate count data $(92,93)$ (Figure 6). This enables models to be generated in the presence of high levels of background microflora (92) and in real food systems (48).

\section{REPORTER OF PATHOGENESIS}

Several recent reports have illustrated the usefulness of bioluminescence to study pathogenicity (5). For example, Mettenleiter and Graewe (94) used a recombinant herpes virus carrying the firefly luciferase genes to monitor activity in single virus-infected cells. Verocytotoxicity of $E$ coli cultures has been measured by transformation of Vero cells with a plasmid containing an intronless, firefly luciferase gene (95). Verotoxin could then be assayed by measuring the decrease in light emission with incubation time (Figure 7). The time taken for the assay could be reduced from three days for the conventional Vero cell cytotoxicity assay to $6 \mathrm{~h}$ for the bioluminescent cell technique, with no loss in sensitivity.

Arguably, the most exciting development is the ability to use bioluminescence to monitor bacterial pathogens in a living host. Contag et al $(75,96,97)$ converted three strains of $S$ typhimurium, which differed in their virulence for mice, to a bioluminescent phenotype through transformation with a plasmid conferring constitutive expression of bacterial luciferase. Using low light imaging, they were able to detect photons transmitted through tissues of the animals infected with the luminescent salmonella, and this allowed localization of the bacteria to specific tissues. Patterns of bioluminescence were observed 


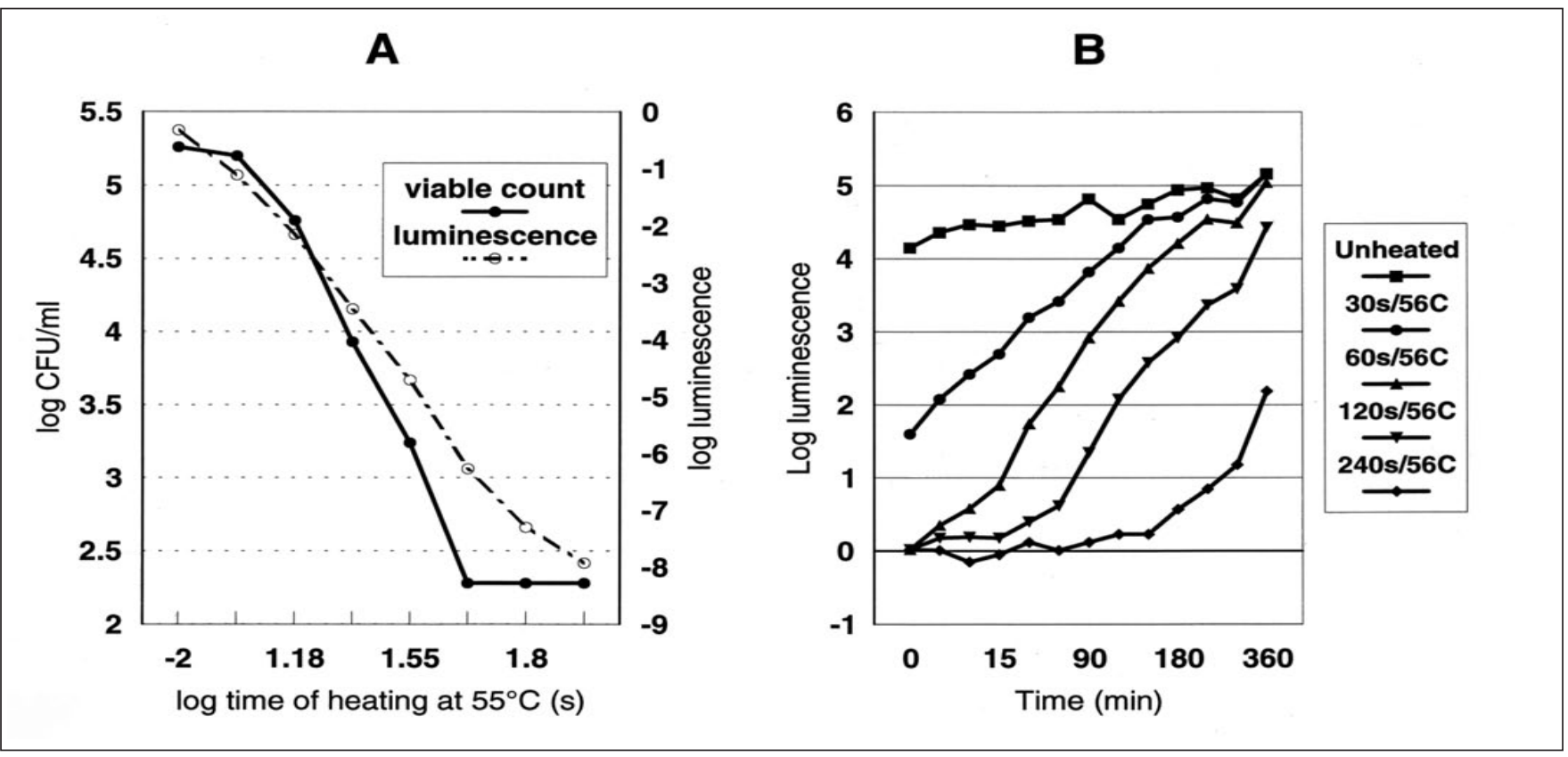

Figure 6) Use of luminescent phenotype of Salmonella typhimurium to assess heat resistance. A Comparison of viable count and bioluminescence, data from reference 92; and B Monitoring recovery from heat treatment using bioluminescence, data from reference 93

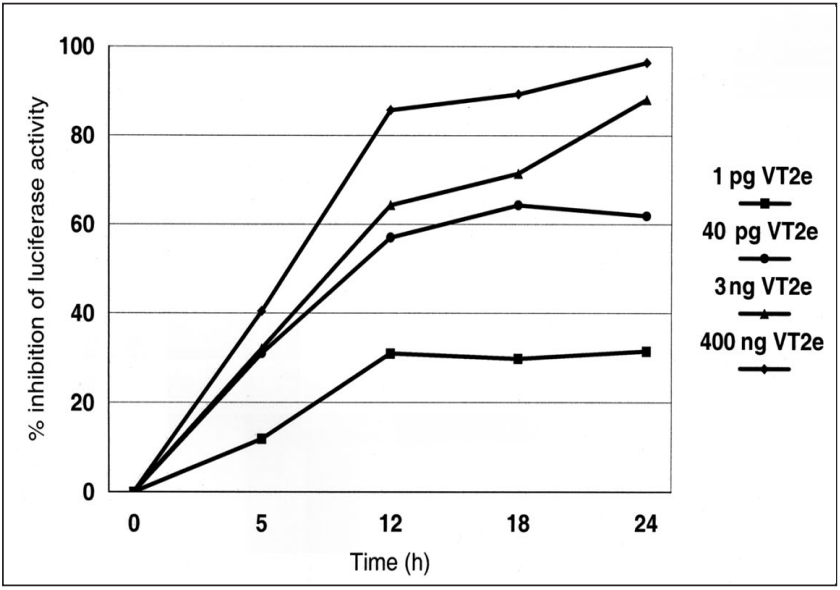

Figure 7) A bioluminescence assay for verocytotoxin production by Escherichia coli 0157:H7. Data from reference 95

that suggested that the caecum played a vital role in salmonella pathogenesis. It was concluded that real time, noninvasive analyses of pathogenic events and pharmacological monitoring could be performed in vivo.

Bacteria are able to sense and respond to their own population densities by releasing and sensing pheromones. This phenomenon is referred to as 'quorum sensing' (98). In Gram-negative bacteria, quorum sensing is under the control of the LuxR family of transcriptional regulators, and the pheromone molecules (synthesized by members of the LuxI family of proteins) are acyl homoserine-lactone (AHSL) analogues. This form of cell-cell communication plays an important role in the regulation of expression of virulence factors involved in pathogenesis and luminescence and may be an important tool for studying these regulatory mechanisms (99). Because pathogenic bacteria use AHSL signals to regulate virulence genes, an understanding of the underlying mechanisms of quorum sensing may lead to the development of novel antivirulence drugs (100). The link between virulence and cell density was demonstrated using a bioluminescent reporter, where it was shown that $S$ enteritidis strains that grew to a higher cell density than the wild type underwent significant morphological changes and became more virulent (101).

\section{BACTERIAL DETECTION USING MOLECULAR BIOLUMINESCENCE}

Ulitzur and Kuhn (73) proposed an elegant method for the detection of bacteria in foods based on the innate specificity of bacteriophage for an appropriate bacterial host. They cloned the lux genes into host-specific phages so that, on infection, the bioluminescent genes would be transferred to the host bacterium where they would be expressed, causing light to be produced. Light is not produced until after infection by the phage because the phage does not possess the intracellular biochemistry to express the genes and the host does not contain the lux genes until transduction occurs. This detection method can be quantitative if the phage is present at optimal concentrations because the amount of light emitted is proportional to the number of infected bacteria. This methodology has been applied to the detection of a variety of bacteria and can even be used for the detection of bacteria directly in foods (102).

Detection of $E$ coli: In their original work, Ulitzur and Kuhn (73) used cell concentrations of $E$ coli W3110 in the range $10^{1}$ to $10^{4}$ colony forming units ( $\left.\mathrm{cfu}\right) / \mathrm{mL}$. The $E$ coli cells were concentrated by membrane filtration and the membranes were placed in scintillation vials. Following addition of a lux modi-

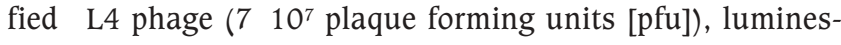
cence in the vials was measured after incubation for 40,60 and $100 \mathrm{mins}$ at $20^{\circ} \mathrm{C}$. The level of light produced was directly related to the initial number of $E$ coli cells present in the sam- 
ple, and as few as 10 cells in the sample could be detected within 100 mins. The lux L4 phage (2 $10^{8} \mathrm{pfu}$ ) was also added to $E$ coli $\mathrm{W} 3110$ cells in sterile milk and luminescence was measured after incubation at $25^{\circ} \mathrm{C}$ for 18,27 and 40 mins (73). Again, initial numbers of $E$ coli cells in milk were directly correlated with light production, and the assay could detect 10 $E$ coli cells/mL of milk within 30 mins. The method was also capable of detecting and enumerating $E$ coli cells in urine samples.

It has been estimated that there are over 100,000 cases of illness caused by enterohemorrhagic $E$ coli annually in the United States, resulting in nearly 80 deaths (103). This has made it desirable to develop simple and rapid methods for the detection of this organism, and bacteriophage-based methods may prove to be valuable. A bacteriophage broadly specific for E coli O157, designated AR1, has been isolated (104). A Luciola mingrelica luc recombinant AR1 has been obtained by simultaneously infecting wild type $E$ coli $0157: \mathrm{H} 7$ with a pBluescript II SK ( \pm ) phagemid containing the luc gene (Promega Corporation, Madison, Wisconsin) and AR1 (105). The transducing phage was capable of detecting $10^{6} \mathrm{E}$ coli $0157: \mathrm{H} 7$ cells $/ \mathrm{mL}$. Detection of Salmonella species: A lux ${ }^{+}$P22 phage has been engineered and used in experiments to infect $S$ typhimurium LT2 (19). When light emission following infection was measured with a luminometer, as few as $10^{2} S$ typhimurium cells could be detected, even when they were present in mixed culture at a ratio of one salmonella cell to $10^{6}$ cells of other bacteria. $S$ typhimurium could be detected with the lux-modified P22 phage in environmental samples including water, soil and sewage sludge (106). These researchers adopted a most probable number technique based on a 15 tube test method, consisting of five tubes containing $10 \mathrm{~mL}, 1 \mathrm{~mL}$ or $0.1 \mathrm{~mL}$ of sample in buffered peptone water. After overnight incubation at $37^{\circ} \mathrm{C}$, subsamples from each tube were transferred to Luria broth in scintillation vials and $6.9 \times 10^{9} \mathrm{pfu}$ of the lux-modified P22 phage added. Light output was measured with a luminometer after 90 mins incubation at $30^{\circ} \mathrm{C}$. There was an excellent correlation between the most probable number obtained by the luminescence method and plate count for all samples, and results were achieved within $24 \mathrm{~h}$. No false positive or false negative results were obtained with the lux $x^{+}$phage method in any of the samples tested.

Chen and Griffiths (102) obtained three recombinant phages carrying the luxAB genes from $V$ harveyi, either by infection of luminescent strains of Salmonella with wild type bacteriophage or by bacteriophage induction from luminescent, lysogenic bacterial cells. Using these phages, it was possible to detect, by photon imaging techniques, light emitted after infection of group B, D and some group C Salmonella species directly in milk, on the surface of chicken meat and even in whole eggs. Eggs contaminated with about $10^{3} \mathrm{cfu} / \mathrm{egg}$ became luminescent after $16 \mathrm{~h}$ incubation, but the detection limit could be decreased to as few as 63 salmonella cells/egg when the incubation period was extended to $24 \mathrm{~h}$. Chen and Griffiths (102) also described a technique whereby Petrifilm (3M, St Paul, Minnesota) and the lux ${ }^{+}$modified phage could be combined for the detection of Salmonella species using x-ray autoradiography for observing light emission.
Detection of $L$ monocytogenes: Loessner et al (107) isolated a bacteriophage, designated A511, which is a Listeria genusspecific, virulent myovirus that infects $95 \%$ of $L$ monocytogenes one-half and four serovars. A recombinant phage was constructed by homologous recombination, which carried the gene for a fused $V$ harveyi LuxAB protein inserted immediately downstream of the major capsid protein gene (cps). Transcription of the lux $A B$ gene was initiated by the cps promoter at 15 to 20 mins after infection, and infected cells were detectable by their bioluminescent phenotype. Following infection and $2 \mathrm{~h}$ incubation period, between $10^{2}$ and $10^{3} \mathrm{~L}$ monocytogenes cells/mL could be detected using a simple luminometer. Loessner and his colleagues (108) subsequently evaluated the use of the A511::luxAB phage for testing contaminated foods and environmental samples for the presence of viable listeria cells. With a short pre-enrichment step of $20 \mathrm{~h}$, the phage was capable of detecting very low initial contamination rates in several foods artificially contaminated with $L$ monocytogenes Scott A cells. In ricotta cheese, chocolate pudding and cabbage, less than one cell/g of food could be detected by comparing the light emission of phage-infected samples to that of controls without the lux $x^{+}$phage. In foods having a large and complex microbial background flora, such as ground beef and soft cheese, at least 10 cells/g were necessary to produce a positive bioluminescence signal. of 348 potentially contaminated natural food and environmental samples, 55 were found to be listeria positive by the lux phage assay versus the 57 positive samples detected by the standard plating procedure. The lux phage procedure detected more positive samples among dairy products and environmental samples, whereas the plating procedure revealed more contaminated meat and poultry samples. Overall, both methods were equally sensitive. However, the minimum time required for detection of listeria with the lux phage assay was $24 \mathrm{~h}$, as opposed to the four days needed by the standard plating method. The phage could also be used in a most probable number technique to provide rapid enumeration of low levels of listeria cells in foods against the background of a competing microflora.

Detection of $M$ tuberculosis: Although foodborne tuberculosis infection has been eradicated in Western countries, the numbers of reported tuberculosis cases are again on the rise, mainly due to the emergence of antibiotic-resistant strains of the organism. Culture methods for $M$ tuberculosis require several weeks, and the need for more rapid testing systems prompted Jacobs et al (109) to investigate bioluminescence. Shuttle phasmid vectors from a number of mycobacteriophages can efficiently deliver recombinant DNA into mycobacteria by infection, and these phasmids are also amenable to genetic manipulation in $E$ coli. A shuttle phasmid from a mycobacteriophage (TM4) that formed plaques, not only on the slow growing $M$ tuberculosis but also on the faster growing species Mycobacterium smegmatis, was constructed by inserting the firefly luc gene downstream of a strong hsp 60 promoter in an $E$ coli cosmid (109). The luc phage infected Bacillus Calmette-Guérin (BCG) vaccine strains of mycobacteria, as well as $M$ tuberculosis and $M$ smegmatis. When mixed in ap-

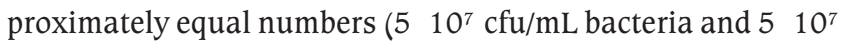


TABLE 3

Properties of luciferases from different sources

\begin{tabular}{llc}
\hline Luciferase & Substrate & $\begin{array}{c}\text { Light emission } \\
\text { wavelength }(\mathbf{n m})\end{array}$ \\
\hline Bacterial & Long chain aldehyde & 490 \\
Firefly & Luciferin & 560 \\
Click beetle & Luciferin & 548 to 593 \\
\hline
\end{tabular}

pfu of phage), light was produced within minutes of infection, although the limit of detection appeared to be $10^{4} \mathrm{cfu} / \mathrm{mL}$. The light output was increased 1000 -fold following incubation for $2 \mathrm{~h}$ at $37^{\circ} \mathrm{C}$ but was still much lower than the light emitted by an equal number of cells transformed with the $l u c^{+}$plasmid. This was probably due to less efficient gene expression in phage-infected cells or phage-mediated inhibition of the cellular metabolism in the host bacterium, resulting in lower intracellular ATP concentrations. The slower growth of $M$ tuberculosis compared with $M$ smegmatis was probably not caused by differences in gene expression because the kinetics of light production were the same in both species (109). It has been claimed that as few as 10 cells of $M$ smegmatis can be detected in $40 \mathrm{~h}$ using $\mathrm{L} 5$ luciferase reporter mycobacteriophage (110).

The versatility of molecular bioluminescence was demonstrated by Jacobs et al (109), who used the bioluminescent $M$ tuberculosis cells obtained by transduction to determine their antibiotic susceptibility. An antibiotic-sensitive strain, an isoniazid-resistant strain and a multiple drug-resistant strain of $M$ tuberculosis were grown and, following incubation with antibiotics, the transducing particles were added to give a multiplicity of infection of 1000 . Luciferin was added after a further incubation step and light production was measured in a luminometer. Resistance to an antibiotic was demonstrated by light production, whereas strains sensitive to the test drug did not luminesce. This methodology allowed a dramatic reduction in the time needed to determine the antibiotic susceptibility of $M$ tuberculosis from two to three months by cultural methods to two to three days by bioluminescence.

Thus, one assay permits both rapid detection and antibiotic susceptibility of the actual causative agent of the disease. This is of considerable importance given the increase in antibioticresistant organisms and the emergence of a number of lifethreatening foodborne pathogens, such as $S$ typhimurium DT104, which possess increased drug resistance.

Detection of $S$ aureus: In an independent study, the author's research group at Guelph has adopted the same strategy as Jacobs et al (109) to detect and determine the antibiotic susceptibilities of mastitis-causing agents, especially $S$ aureus (105). A battery of five phages were identified that could infect all strains of $S$ aureus tested, whether they were isolated from mastitic cows or from foods implicated in foodborne illness. A plasmid incorporating the luxAB genes fused to a staphylococcal cadmium-resistant gene promoter was introduced into staphylococcal phages by homologous recombination. Using these recombinant phages, it was possible to detect $10^{6} \mathrm{~S}$ aureus cells/mL in broth cultures. The luminescent strains ob- tained after transduction could be used to test for antibiotic susceptibility.

Multiplex assays: The luciferases encoded by different organisms have distinct properties $(1,111,112)$ which can be used to develop systems that can detect, and differentiate between, more than one bacterium in a single assay. For example, the luciferase encoded by the bacterial lux genes has a requirement for a long chain aldehyde and emits light at a wavelength of about $490 \mathrm{~nm}$, whereas the firefly luc gene encodes an enzyme which uses luciferin and produces light at a wavelength near $560 \mathrm{~nm}$ (Table 3). Thus, the light produced from recombinant bacteria containing either the lux or luc genes can be easily distinguished, either on the basis of substrate specificity or emission wavelength. Lux-modified phages specific for Salmonella species and $S$ aureus, and $l u c^{+}$phages that infect only $E$ coli 0157 strains have been engineered $(102,105)$. With the aid of a $500 \mathrm{~nm}$ cut-off filter, it is easily possible to differentiate between bacteria expressing the lux genes and those expressing luc by photon imaging.

This method of differentiating between microorganisms has great potential for studying microbial interactions directly in food systems, and work in this area is being conducted in the author's laboratory.

Advantages and limitations of the method: $L u x$-modified phage-based detection methods are attractive to the food microbiologist because they offer a nondestructive, rapid and easy-to-use alternative to other technologies. A particularly attractive feature of these techniques is their ability to detect the presence of luminescent microorganisms directly on food surfaces through instrumentation that allows low light imaging. Although Ulitzur and Kuhn (73) have claimed that it is possible to detect as few as 10 bacterial cells/mL directly in milk using transduction of lux genes, no research has been published that confirms this observation. However, even if the method is unable to detect directly the low number of pathogens that may be present in food, the system is sensitive enough that dramatic reductions in enrichment times can be achieved $(106,113)$. As discussed previously, recent work in the author's laboratory has shown that simple techniques can be used to differentiate between organisms expressing luciferase genes from different sources (eg, lux and luc genes). The application of this method to food opens the door for the development of 'single shot' assays capable of detecting more than one type of bacterium. The economy of this approach, in terms of both reagents and labour, would be appealing to food microbiologists.

Some of the difficulties that have to be overcome are associated with propagation and stability of the phage, as well as poor expression of the luciferase genes in the host. This is especially true for Gram-positive bacteria, but the use of lux $A B$ gene fusions may go some way to alleviating this problem. The identification of suitable gene promoters to regulate expression of the luciferase gene is also a key factor in optimizing the phage-mediated assay.

The specificity of the method is only limited by the identification of suitable bacteriophages capable of only infecting the target bacterium. Bacteriophages generally have a narrow host 
range, which is limited in most cases to single bacterial species. For certain bacteria, such as Salmonella species, phages are well characterized, but in other species, phages have still to be identified that infect an acceptable proportion of strains. Even when suitable bacteriophages are available, the lack of information on the phage genome can be a hindrance to the development of suitable assays.

\section{CONCLUSIONS}

The phenomemon of bioluminescence can be used in several ways to provide data that can help the food microbiologist achieve the goal of safer food. It can provide a way of detecting potential pathogens in food through the use of lux-modified phage. By creating organisms with a bioluminescent phenotype, it is possible to gain information on the way foodborne pathogens survive in food and interact with their environment. The potential of the technique has not been fully realized, but interest in applying molecular bioluminescence to solve problems related to the microbiological safety of foods is increasing.

\section{REFERENCES}

1. Campbell AK. Living light: biochemistry, function and biomedical applications. Essays Bioch 1989;24:41-81.

2. Meighen EA. Enzymes and genes from the lux operons of bioluminescent bacteria. Ann Rev Microbiol 1988;42:151-76.

3. Meighen EA. Molecular biology of bacterial bioluminescence. Microbiol Rev 1991;55:123-42.

4. Meighen EA. Molecular biology of bioluminescence. In: Stanley PE, Kricka LJ, eds. Bioluminescence and Chemiluminescence: Current Status. Chichester: John Wiley and Sons Ltd, 1991:3-10.

5. Meighen EA. Genetics of bacterial bioluminescence. Annu Rev Genet 1994;28:117-39.

6. Meighen EA, Dunlap PV. Physiological, biochemical and genetic control of bacterial bioluminescence. Adv Microb Physiol 1993;34:1-67.

7. Jacobs M, Hill PJ, Stewart GSAB. Highly bioluminescent Bacillus subtilis obtained through high-level expression of a luxAB fusion gene. Mol Gen Genet 1991;230:251-6.

8. Baker J, Griffiths MW, Collins-Thompson D. Bacterial bioluminesence: Application in food microbiology. J Food Prot 1992;55:62-70.

9. Chatterjee J, Meighen EA. Biotechnological applications of bacterial bioluminescence (lux) genes. Photochem Photobiol 1995;62:641-50.

10. Dodd CER, Stewart GSAB, Waites WM. Biotechnology-based methods for the detection, enumeration and epidemiology of food poisoning and spoilage organisms. Biotechnol Genet Eng Rev 1990;8:1-50.

11. Hill PJ, Stewart GSAB. Use of lux genes in applied biochemistry. J Biolumin Chemilumin 1994;9:211-5.

12. Hill PJ, Rees CED, Winson MK, Stewart GSAB. The application of lux genes. Biotechnol Appl Biochem 1993;17:3-14.

13. Jassim SAA, Ellison A, Denyer SP, Stewart GSAB. In vivo bioluminescence - a cellular reporter for research and industry. J Biolumin Chemilumin 1990;5:115-22.

14. Stewart GSAB. In vivo bioluminescence: new potentials for microbiology. Lett Appl Microbiol 1990;10:1-8.

15. Stewart GSAB. Challenging food microbiology from a molecular perspective. Microbiology 1997;143:2099-108.

16. Stewart GSAB, Williams P. lux genes and the applications of bacterial bioluminescence. J Gen Microbiol 1992;138:1289-300.

17. Stewart GSAB, Williams P. Shedding new light on food microbiology. The genes encoding bacterial bioluminescence are enabling microbiologists to better understand the complexities of bacterial adaptation and survival. ASM News 1993;59:241-6.

18. Stewart GSAB, Denyer SP, Lewington J. Microbiology illuminated: gene engineering and bioluminescence. Trends Food Sci Technol 1991;2:7-10.

19. Stewart G, Smith T, Denyer S. Genetic engineering for bioluminescent bacteria. Food Sci Technol Today 1989;3:19-22.

20. Schauer AT. Visualizing gene expression with luciferase fusions. Trends Biotechnol 1988;6:23-7.

21. Nordeen SK. Luciferase reporter gene vectors for analysis of promoters and enhancers. Biotechniques 1988;6:454-7.

22. O'Kane DJ, Lingle WL, Wampler JE, Legocki M, Legocki RP, Szalay AA. Visualization of bioluminescence as a marker of gene expression in rhizobium-infected soybean root nodules. Plant Mol Biol 1988;10:387-99.

23. Hooper CE, Ansorge RE, Browne HM, Tomkins P. CCD imaging of luciferase gene expression in single mammalian cells. J Biolumin Chemilumin 1990;5:123-30.

24. Masuko M, Hosoi S, Hayakawa T. A novel method for detection and counting of single bacteria in a wide field using an ultra-high-sensitivity TV camera without a microscope. FEMS Microbiol Lett 1991;81:287-90.

25. Blouin K, Walker SG, Smit J, Turner RFB. Characterization of in vivo reporter systems for gene expression and biosensor applications based on luxAB luciferase genes. Appl Environ Microbiol 1996;62:2013-21.

26. Chalfie M. Green fluorescent protein. Photochem Photobiol 1995;62:651-6.

27. Chalfie M, Tu Y, Euskirchen G, Ward WW, Prasher DC. Green fluorescent protein as a marker for gene expression. Science 1994;263:802-5.

28. Unge A, Tombolini R, Mølbak L, Jansson JK. Simultaneous monitoring of cell number and metabolic activity of specific bacterial populations with a dual gfp-luxAB marker system. Appl Environ Microbiol 1999;65:813-21.

29. Sheehan BJ, Foster TJ, Dorman CJ, Park S, Stewart GSAB. Osmotic and growth-phase dependent regulation of the eta gene of Staphylococcus aureus: a role for DNA supercoiling. Mol Gen Genet 1992;232:49-57.

30. Timmins BS, Holland KT. Shift-down in growth rate rather than high cell density induces toxic shock syndrome toxin-1 gene expression in Staphylococcus aureus. FEMS Microbiol Lett 1999;172:173-7.

31. Cossart P, Mengaud J. Listeria monocytogenes, a model system for the study of intracellular parasitism. Mol Biol Med 1989;6:463-74.

32. Mengaud J, Braun-Breton C, Cossart P. Identification of phosphatidylinositol specific phospholipase $\mathrm{C}$ activity in Listeria monocytogenes: a novel type of virulence factor. Mol Microbiol $1991 ; 5: 367-72$.

33. Mengaud J, Dramsi S, Govin E, Vazquez-Boland JA, Milon G, Cossart P. Pleiotropic control of Listeria monocytogenes virulence factors by a gene that is autoregulated. Mol Microbiol 1991;5:2273-83.

34. Park SF, Stewart GSAB, Kroll RG. The use of bacterial luciferase of monitoring the environmental regulation of expression of genes encoding virulence factors in Listeria monocytogenes. J Gen Microbiol 1992;138:2619-27.

35. Renzoni A, Klarsfield A, Dramsi S, Cossart P. Evidence that PrfA, the pleiotropic activator of virulence genes in Listeria monocytogenes, can be present but inactive. Infect Immun 1997;65:1515-8.

36. Carmi OA, Stewart GSAB, Ulitzur S, Kuhn J. Use of bacterial luciferase to establish a promoter probe vehicle, capable of non-destructive real-time analysis of gene expression in Bacillus spp. J Bacteriol 1987;169:2165-70.

37. Cook N, Silcock DJ, Waterhouse RN, Prosser JI, Glover LA, Killham K. Construction and detection of bioluminescent strains of Bacillus subtilis. J Appl Bacteriol 1993;75:350-9.

38. Hall LR, Harding SE, Waites WM. Use of bioluminescence to study heat resistance of spores of Bacillus megaterium KM. J Appl Bacteriol 1990;69:xxiv.

39. Hill PJ, Hall L, Harding SE, et al. Bioluminescence and spores as biological indicators of inimical processes. Proceedings of the Society of Applied Bacteriology: 62nd Annual Meeting. July 13-16, 1993, Nottingham:v-vi.

40. Dodd CER, Sharman RL, Bloomfield SF, Booth IR, Stewart GSAB. Inimical processes-bacterial self-destruction and sub-lethal injury. Trends Food Sci Technol 1997;8:238-41.

41. Ellison A, Perry SF, Stewart GSAB. Bioluminescence as a real-time monitor of injury and recovery in Salmonella typhimurium. Int J Food Microbiol 1991;12:323-32.

42. Ferguson Y, Glover LA, McGillivray DM, Prosser JI. Survival and activity of lux-marked Aeromonas salmonicida in seawater. Appl Environ Microbiol 1995;61:3494-8.

43. Oliver JD, McDougald D, Barrett T, Glover LA, Prosser JI. Effect of temperature and plasmid carriage on nonculturability in organisms targeted for release. FEMS Microbiol Ecol 1995;17:229-38.

44. Duncan S, Glover LA, Killham K, Prosser JI. Luminescence-based detection of activity of starved and viable but nonculturable bacteria. Appl Environ Microbiol 1994;60:1308-16.

45. Bloomfield SF, Stewart GSAB, Dodd CER, Booth IR, Power EGM. The viable but non-culturable phenomenon explained? Microbiology 1998;144:1-3.

46. Park SF, Stirling DA, Hulton CS, Booth IR, Higgins CF, Stewart GSAB. A novel, non-invasive promoter probe vector: cloning of the osmoregulated proU promoter of Escherichia coli K12. Mol Microbiol 1989;3:1011-23.

47. Chen J, Griffiths MW. Luminescent Salmonella strains as real time reporters of growth and recovery from sublethal injury in food. Int J Food Microbiol 1996;31:27-43.

48. Bautista DA, Chen J, Barbut S, Griffiths MW. Use of an autobioluminescent Salmonella Hadar to monitor the effect of lactic acid on poultry carcasses. J Food Prot 1998;61:1439-45.

49. Rees CED, Dodd CER, Gibson PT, Booth IR, Stewart GSAB. The significance of bacteria in stationary phase to food microbiology. Int J Food Microbiol $1995 ; 28: 263-75$

50. Hengge Aronis R. Back to log phase-sigma-S as a global regulator in osmotic control of gene expression in Escherichia coli. Mol Microbiol 1996;21:887-93

51. Kowarz L, Coynault C, Robbe-Saule V, Norel FTI. The Salmonella typhimurium katF (rpoS) gene-cloning, nucleotide-sequence and 
regulation of $s p v R$ and $s p v A B C D$ virulence plasmid genes. J Bacteriol 1994; $176: 6852-60$.

52. Swift S, Stewart GSAB. Luminescence as a signal of $s p v A$ expression. In: Campbell AK, Kricka LJ, Stanley PE, eds. Bioluminescence and Chemiluminescence: Fundamentals and Applied Aspects. Chichester: John Wiley and Sons, 1994:93-6.

53. Aldsworth TG, Sharman R, Dodd CER, Stewart GSAB. A competitive microflora increases the resistance of Salmonella typhimurium to inimical processes: Evidence for a suicide response. Appl Environ Microbiol 1998;64:1323-7.

54. Thompson JM, Stewart GSAB, Dodd CER. RpoS function in Salmonella Typhimurium LT2 monitored in a skim milk model food. J Food Prot 1999;62:70-2

55. Belkin S, Smulski DR, Vollmer AC, Van Dyk TK, LaRossa RA. Oxidative stress detection with Escherichia coli harboring a katG ::lux fusion. Appl Environ Microbiol 1996;62:2252-6.

56. Ben-Israel O, Ben-Israel H, Ulitzur S. Identification and quantification of toxic chemicals by use of Escherichia coli carrying lux genes fused to stress promoters. Appl Environ Microbiol 1998;64:4346-52.

57. Dukan S, Dadon S, Smulski DR, Belkin S. Hypochlorous acid activates the heat shock and soxRS systems of Escherichia coli. Appl Environ Microbiol 1996;62:4003-8

58. Van Dyk TK, Reed TR, Vollmer AC, LaRossa RA. Synergistic induction of the heat shock response in Escherichia coli by simultaneous treatment with chemical inducers. J Bacteriol 1995;177:6001-4.

59. Van Dyk TK, Smulski DR, Reed TR, Belkin S, Vollmer AC, LaRossa RA. Responses to toxicants of an Escherichia coli strain carrying a uspA::lux genetic fusion and an E. coli strain carrying a grpE::lux fusion are similar. Appl Environ Microbiol 1995;61:4124-7.

60. Vollmer AC, Belkin S, Smulski DR, Vandyk TK, Larossa RA. Detection of DNA damage by use of Escherichia coli carrying recA::lux, uvrA::lux, or alkA::lux reporter plasmids. Appl Environ Microbiol 1997;63:2566-71.

61. Chen J, Clarke RC, Griffiths MW. Use of luminescent strains of Salmonella enteritidis to monitor contamination and survival in eggs. J Food Prot 1996;59:915-21.

62. Fabricant JD, Chalmers JH Jr, Bradbury MW. Bioluminescent strains of $E$ coli for the assay of biocides. Bull Environ Contaminat Toxicol 1995;54:90-5.

63. Stewart GSAB, Jassim SAA, Denyer SP. Mechanisms of action and rapid biocide testing. In: Denyer SP, Hugo WB, eds. Mechanisms of Action of Chemical Biocides: Their Study and Exploitation. Oxford: Blackwell Scientific Publications, 1991:319-29.

64. Simpson ML, Sayler GS, Applegate BM, et al. Bioluminescent-bioreporter integrated circuits form novel whole-cell biosensors. Trends Biotechnol 1998; $16: 332-8$.

65. Wirtanen G, Nissinen V, Tikkanen L, Mattila Sandholm T. Use of Photobacterium leiognathi in studies of process equipment cleanability. Int J Food Sci Technol 1995;30:523-33.

66. Walker AJ, Jassim SAA, Holah JT, Denyer SP, Stewart GSAB. Bioluminescent Listeria monocytogenes provide a rapid assay for measuring biocide efficacy. FEMS Microbiol Lett 1992;91:251-5.

67. Walker AJ, Holah JT, Denyer SP, Stewart GSAB. The antibacterial activity of Virkon measured by colony growth and bioluminescence of lux recombinant Listeria monocytogenes. Lett Appl Microbiol 1992;15:80-2.

68. Park SF, Nissen U, Stewart GSAB. The cloning and expression of luxAB in Listeria monocytogenes. In: Stanley PE, Kricka LJ, eds. Bioluminescence and Chemiluminescence: Current Status. Chichester: John Wiley and Sons Ltd, 1991:35-8.

69. Dhir VK, Dodd CER. Susceptibility of suspended and surface-attached Salmonella enteritidis to biocides and elevated temperatures. Appl Environ Microbiol 1995;61:1731-8.

70. Lee S, Suzuki M, Tamiya E, Karube I. Microbial detection of toxic compounds utilizing recombinant DNA technology and bioluminescence. Anal Chim Acta 1991;244:201-6.

71. Virta M, Aekerman KEO, Saviranta P, Oker Blom C, Karp MT. Real-time measurement of cell permeabilization with low-molecular-weight membranolytic agents. J Antimicrob Chemother 1995;36:303-15.

72. Hibma AM, Jassim SAA, Griffiths MW. Infection and removal of L-forms of Listeria monocytogenes with bred bacteriophage. Int J Food Microbiol 1997;34:197-207.

73. Ulitzur S, Kuhn J. Introduction of lux genes into bacteria: a new approach for specific determination of bacteria and their antibiotic susceptibility. In: Schlomerich J, Andreesen R, Kapp A, et al, eds. Bioluminescence and Chemiluminescence New Perspectives. Chichester: John Wiley and Sons, 1987:463-72.

74. Hickey MJ, Arain TM, Shawar RM, et al. Luciferase in vivo expression technology: Use of recombinant mycobacterial reporter strains to evaluate antimycobacterial activity in mice. Antimicrob Agents Chemother 1996;40:400-7.

75. Contag CH, Contag PR, Mullins JI, Spilman SD, Stevenson DK, Benaron DA. Photonic detection of bacterial pathogens in living hosts. Mol Microbiol 1995; 18:593-603.

76. Arain TM, Resconi AE, Singh DC, Stover CK. Reporter gene technology to assess activity of antimycobacterial agents in macrophages. Antimicrob Agents Chemother 1996;40:1542-4.

77. Angell P, Arrage AA, Mittelman MW, White DC. On line, non-destructive biomass determination of bacterial biofilms by fluorometry. J Microbiol Method 1993;18:317-27

78. Denyer SP, Jassim SAA, Stewart GSAB. In vivo bioluminescence for studying the adhesion of bacteria. Biofouling 1991;5:125-32.

79. Mittelman MW, King JMH, Sayler GS, White DC. On-line detection of bacterial adhesion in a shear gradient with bioluminescence by a Pseudomonas fluorescens (lux) strain. J Microbiol Method 1992;15:53-60.

80. Nivens DE, Palmer RJ Jr, White DC. Continuous nondestructive monitoring of microbial biofilms: A review of analytical techniques. J Ind Microbiol 1995; $15: 263-76$

81. Mittelman MW, Packard J, Arrage AA, Bean SL, Angell P, White DC. Test systems for determining antifouling coating efficacy using on-line detection of bioluminescence and fluorescence in a laminar-flow environment. J Microbiol Method 1993;18:51-60.

82. Jassim SAA, Camprubi S, Tomas JM, et al. In vivo bioluminescence for studying bacterial adhesion and in vitro phagocytosis. In: Szalay A, Kricka L, Stanley P, eds. Bioluminescence and Chemiluminescence: Status Report. Chichester: John Wiley and Sons Ltd, 1993:491-5.

83. Rice JF, Fowler RF, Arrage AA, White DC, Sayler GS. Effects of external stimuli on environmental bacterial strains harboring an algD-lux bioluminescent reporter plasmid for the study of corrosive biofilms. J Ind Microbiol 1995; 15:318-28.

84. Chumkhunthod P, Schraft H, Griffiths MW. Rapid monitoring method to assess the efficacy of sanitizers against Pseudomonas putida biofilms. J Food Prot 1998;61:1043-6.

85. Hibma AM, Jassim SAA, Griffiths MW. In vivo bioluminescence to detect the attachment of L-forms of Listeria monocytogenes to food and clinical contact surfaces. Int J Food Microbiol 1996;33:157-67.

86. Siragusa GR, Nawotka K, Spilman SD, Contag PR, Contag CH. Real-time monitoring of Escherichia coli $0157: \mathrm{H} 7$ adherence to beef carcass surface tissues with a bioluminescent reporter. Appl Environ Microbiol 1999;65:1738-45.

87. Prosser JI, Killham K, Glover LA, Rattray EAS. Luminescence-based systems for detection of bacteria in the environment. Crit Rev Biotechnol 1996;16:157-83.

88. Hudson LM, Chen J, Hill AR, Griffiths MW. Bioluminescence - a rapid indicator of Escherichia coli 0157:H7 in selected yogurt and cheese varieties. J Food Prot 1997;60:891-7.

89. Ramsaran H, Chen J, Brunke B, Hill A, Griffiths MW. Survival of bioluminescent Listeria monocytogenes and $E$ coli $0157: \mathrm{H} 7$ in soft cheeses. J Dairy Sci 1998;81:1810-7.

90. Tomicka A, Chen J, Barbut S, Griffiths MW. Survival of bioluminescent E coli 0157:H7 in a model system representing fermented sausage production. J Food Prot 1997;60:1487-92.

91. Fratamico PM, Deng MY, Strobaugh TP, Palumbo SA. Construction and characterization of Escherichia coli 0157:H7 strains expressing firefly luciferase and green fluorescent protein and their use in survival studies. J Food Prot 1997;60:1167-73.

92. Duffy G, Ellison A, Anderson W, Cole MB, Stewart GSAB. Use of bioluminescence to model the thermal inactivation of Salmonella typhimurium in the presence of a competitive microflora. Appl Environ Microbiol 1995;61:3463-5.

93. Ellison A, Anderson W, Cole MB, Stewart GSAB. Modelling the thermal inactivation of Salmonella typhimurium using bioluminescence data. Int I Food Microbiol 1994;23:467-77.

94. Mettenleiter TC, Graewe W. Video imaging of firefly luciferase activity to identify and monitor herpesvirus infection in cell culture. J Virol Methods 1996;59:155-60.

95. Hammermueller JD, Gyles CL. The development of a rapid bioluminescent Vero cell assay. In: Karmali MA, Goglio AG, eds. Recent advances in verocytotoxin-producing Escherichia coli infections. Amsterdam: Elsevier, 1994:113-6.

96. Contag PR, Olomu IN, Stevenson DK, Contag CH. Bioluminescent indicators in living mammals. Nat Med 1998;4:245-7.

97. Contag $\mathrm{CH}$, Spilman SD, Contag PR, et al. Visualizing gene expression in living mammals using a bioluminescent reporter. Photochem Photobiol 1997;66:523-31

98. Swift S, Throup JP, Williams P, Salmond GPC, Stewart GSAB. Quorum sensing: a population density component in the determination of bacterial phenotype. Trends Biochem Sci 1996;21:214-9.

99. Winson MK, Camara M, Latifi A, et al. Multiple N-acyl-L-homoserine lactone signal molecules regulate production of virulence determinants and secondary metabolites in Pseudomonas aeruginosa. Proc Natl Acad Sci (USA) 1995;92:9427-31.

100. Parsek MR, Val DL, Hanzelka BL, Cronan JE Jr, Greenberg EP. Acyl homoserine-lactone quorum sensing signal generation. Proc Natl Acad Sci (USA) 1999; 96:4360-5.

101. Guard-Petter J. Variants to smooth Salmonella enterica serovar Enteritidis that grow to higher cell density than the wild type are more virulent. Appl Environ Microbiol 1998;64:2166-72. 
102. Chen J, Griffiths MW. Salmonella detection in eggs using lux $x^{+}$ bacteriophages. J Food Prot 1996;59:908-14.

103. Mead PS, Slutsker L, Dietz V, et al. Food-related illness and death in the United States. Emerg Infect Dis 1999;5:607-25.

104. Ronner AB, Cliver DO. Isolation and characterization of a coliphage specific for Escherichia coli 0157:H7. J Food Prot 1990;53:944-7.

105. Pagotto F, Brovko L, Griffiths MW. Phage-mediated detection of Staphylococcus aureus and E coli 0157:H7 using bioluminescence. Symposium on Bacteriological Quality of Raw Milk. Brussels International Dairy Federation, 1996:152-6.

106. Turpin PE, Maycroft KA, Bedford J, Rowlands CL, Wellington EMH. A rapid luminescent-phage based MPN method for the enumeration of Salmonella typhimurium in environmental samples. Lett Appl Microbiol 1993;16:24-7.

107. Loessner MJ, Rees CED, Stewart GSAB, Scherer S. Construction of luciferase reporter bacteriophage $A 511:$ luxAB for rapid and sensitive detection of viable Listeria cells. Appl Environ Microbiol 1996;62:1133-40.

108. Loessner MJ, Rudolf M, Scherer S. Evaluation of luciferase reporter bacteriophage A511::luxAB for detection of Listeria monocytogenes in contaminated foods. Appl Environ Microbiol 1997;63:2961-5.

109. Jacobs WR Jr, Barletta RG, Udani R, et al. Rapid assessment of drug susceptibilities of Mycobacterium tuberculosis by means of luciferase reporter phages. Science 1993;260:819-22.

110. Sarkis GJ, Jacobs WR, Hatfull GF. L5 luciferase reporter mycobacteriophages - a sensitive tool for the detection and assay of live mycobacteria. Mol Microbiol 1995;15:1055-67.

111. Cebolla A, Vazquez ME, Palomares AJ. Expression vectors for the use of eukaryotic luciferases as bacterial markers with different colors of luminescence. Appl Environ Microbiol 1995;61:660-8.

112. Hastings JW. Chemistries and colors of bioluminescent reactions: A review. Gene 1996;173:5-11.

113. Kodicara CP, Crew HH, Stewart GSAB. Near on-line detection of enteric bacteria using lux recombinant bacteriophage. FEMS Microbiol Lett 1991;83:261-6.

114. Delong EF, Steinhauer D, Israel A, Nealson KH. Isolation of the lux genes from Photobacterium leiognathi and expression in Escherichia coli. Gene 1987;54:203-10.

115. Mancini JA, Boylan M, Soly RR, Graham AF, Meighen EA. Cloning and expression of the Photobacterium phosphoreum luminescence system demonstrates a unique lux gene organization. J Biol Chem 1988;263:14308-14

116. Engebrecht J, Nealson KH, Silverman M. Bacterial bioluminescence: isolation and genetic analysis of functions from Vibrio fischeri. Cell 1983;32:773-81.

117. Baldwin TO, Berends T, Bunch TA, et al. Cloning of the luciferase structural genes from Vibrio harveyi and the expression of bioluminescence in Escherichia coli. Biochemistry 1984;23:3663-7.

118. Belas R, Mileham A, Cohn D, Hilmen M, Simon M, Silverman M. Bacteria bioluminescence: isolation and expression of the luciferase genes from Vibrio harveyi. Science 1982;218:791-3.

119. Cohn DH, Ogden RC, Abelson JN, et al. Cloning of Vibrio harveyi luciferase genes: use of a synthetic oligonucleotide probe. Proc Natl Acad Sci (USA) 1983;80:120-3.

120. Frackman S, Anhalt M, Nealson KH. Cloning, organization and expression of the bioluminescence genes of Xenorhabdus luminescens. J Bacteriol 1990;172:5767-73.

121. Szittner R, Meighen E1. Nucleotide sequence, expression and properties of luciferase coded by lux genes from a terrestrial bacterium. J Biol Chem 1990;265:16581-7.

122. Masuda T, Tatsumi M, Nakano E. Cloning and sequence analysis of cDNA for luciferase of a Japanese firefly, Luciola cruciata. Gene 1989;77:265-70

123. Tatsumi H, Kajiyama N, Nakano E. Molecular cloning and expression in Escherichia coli of a cDNA clone encoding luciferase of a firefly, Luciola lateralis. Biochim Biophys Acta 1992;1131:161-5.

124. Devine JH, Kutuzova GD, Green VA, Ugarova NN, Baldwin TO. Luciferase from the East European firefly $L$ mingrelica: cloning and nucleotide sequence of the cDNA, overexpression in Escherichia coli and purification of the enzyme. Biochim Biophys Acta 1993;1173:121-32.

125. De Wet JR, Wood KV, Helinski DR, DeLuca M. Cloning of firefly luciferase cDNA and the expression of active luciferase in Escherichia coli. Proc Natl Acad Sci (USA) 1985;82:7870-3.

126. Wood KV, Lam YA, Seliger HH, McElroy WD. Complementary DNA coding click beetle luciferases can elicit bioluminescence of different colors. Science 1989;244:700-2.
127. Prasher DC, McCann CO, Longiaru M, Cormier MJ. Sequence comparisons of complementary DNAs encoding aequorin isotypes. Biochemistry 1987;26:1326-32.

128. Thompson EM, Nagata S, Tsuji FI. Cloning and expression of cDNA from the marine ostracod Vargula hilgendorfii. Proc Natl Acad Sci (USA) 1989;86:6567-71.

129. Lorenz WW, McCann RO, Longiaru M, Cormier MJ. Isolation and expression of a cDNA encoding Renilla reniformis luciferase. Proc Nat Acad Sci (USA) 1991;88:4438-42.

130. Tsuji FI, Inouye S. Cloning and sequence analysis of cDNA for the $\mathrm{Ca}^{2+}$-activated photoprotein, clytin. FEBS Letters 1993;315:343-6.

131. Illarionov BA, Marcova SV, Bondar VA, Vysotsky ES, Gitelson JI. [Cloning and expression of CDNA and $\mathrm{Ca} 2+$-activated photoprotein obelin from the hydroid polyp Obelia longissima]. Dokl Akad Nauk SSSR 1992;326:911-4

132. Matz MV, Fradkov AF, Labas YA, et al. Fluorescent proteins from nonbioluminescent Anthozoa species. Nat Biotechnol 1999; 17:969-73

133. Ferguson Y, McGillivray DM, Prosser JI, Glover LA. Luminescence-based detection of the fish pathogen Aeromonas salmonicida. 3rd International Marine Biotechnology Conference 1994; Tromsoe, Norway, 1994:128. [Abst]

134. Boivin R, Chalifour F-P, Dion P. Construction of a Tn 5 derivative encoding bioluminescence and its introduction in Pseudomonas, Agrobacterium and Rhizobium. Mol Gen Genet 1988;213:50-5.

135. Shaw JJ, Kado CI. Development of a Vibrio gene-set to monitor phytopathogenic bacteria during the on-going disease process in a non-disruptive manner. BioTechnology 1986;4:60-4.

136. Legocki RP, Legocki M, Baldwin TO, Szalay AA. Bioluminescence in soybean root nodules: demonstration of a general approach to assay gene expression in vivo by using bacterial luciferase. Proc Natl Acad Sci (USA) 1986;83:9080-4

137. Blissett JS, Stewart GSAB. In vivo bioluminescent determination of apparent $\mathrm{K}_{\mathrm{m}}$ 's for aldehyde in recombinant bacteria expressing luxA/B. Lett Appl Microbiol 1989;9:149-52.

138. Flemming CA, Lee H, Trevors JT. Bioluminescent most-probable-number method to enumerate lux-marked Pseudomonas aeruginosa UG2Lr in soil. Appl Environ Microbiol 1994;60:3458-61.

139. Engebrecht J, Simon M, Silverman M. Measuring gene expression with light. Science 1985;227:1345-7.

140. Kaniga K, Sory M-P, Delor I, Saegerman C, Limet JN, Cornelis GR. Monitoring of Yersinia enterocolitica in murine and bovine feces on the basis of the chromosomally integrated luxAB marker gene. Appl Environ Microbiol 1992;58:1024-6

141. Karp M, Meyer P. Expression of bacterial luciferase genes from Vibrio harveyi in Bacillus subtilis and Escherichia coli. Biochim Biophys Acta 1989;1007:84-90.

142. Lampinen J, Koivisto L, Wahlsten M, Mäntsälä P, Karp M. Expression of luciferase genes from different origins in Bacillus subtilis. Mol Gen Genet 1992;232:498-505.

143. Wang G, Mayerhofer R, Langridge WHR, et al. Expression of a bacterial luciferase marker gene in Bacillus species. In: Szalay A, Kricka L, Stanley P, eds. Bioluminescence and Chemiluminescence: Status Report. Chichester: John Wiley and Sons Ltd, 1993:232-6.

144. Purdy D, Park SF. Heterologous gene expression Campylobacter coli: The use of bacterial luciferase in a promoter probe vector. FEMS Microbiol Let 1993;111:233-7.

145. Phillips-Jones MK. Bioluminescence (lux) expression in the anaerobe Clostridium perfringens. FEMS Microbiol Lett 1993;106:265-70.

146. Ahmad KA, Stewart GSAB. The production of bioluminescent lactic acid bacteria suitable for the rapid assessment of starter culture activity in milk. J Appl Bacteriol 1991;70:113-20.

147. Eaton TJ, Shearman CA, Gasson MJ. The use of bacterial luciferase genes as reporter genes in Lactococcus: Regulation of the Lactococcus lactis subsp. lactis lactose genes. J Gen Microbiol 1993;139:1495-501.

148. Park SF, Stewart GSAB. High efficiency transformation of Listeria monocytogenes by electroporation of penicillin-treated cells. Gene 1990;94:129-32.

149. Jacobs MF, Tynkkynen S, Sibakov M. Highly bioluminescent Streptococcus thermophilus strain for the detection of dairy-relevant antibiotics in milk. Appl Microbiol Biotechnol 1995;44:405-12.

150. Kirchner G, Roberts JL, Gustafson GD, Ingolia TD. Active bacterial luciferase from a fused gene: expression of a Vibrio harveyi luxAB translational fusion in bacteria, yeast and plant cells. Gene 1989;81:349-54. 


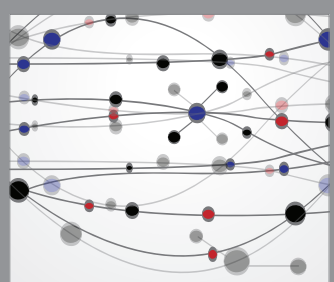

The Scientific World Journal
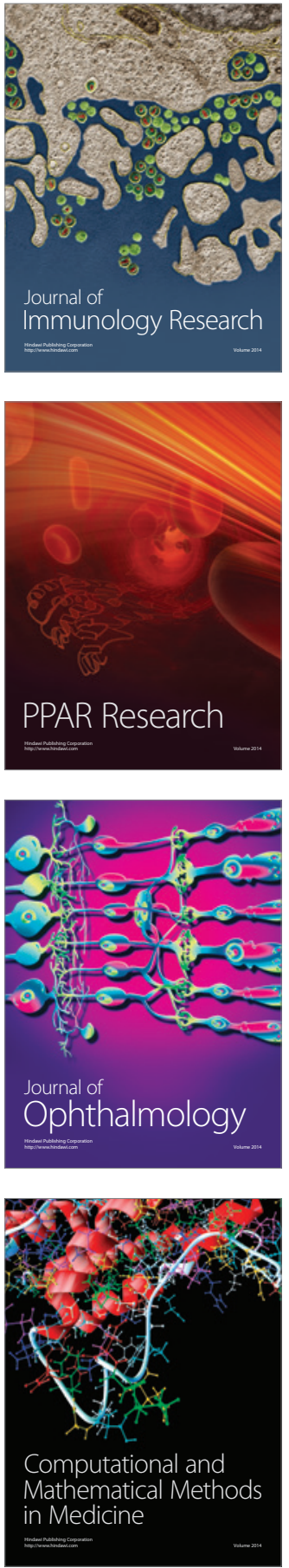

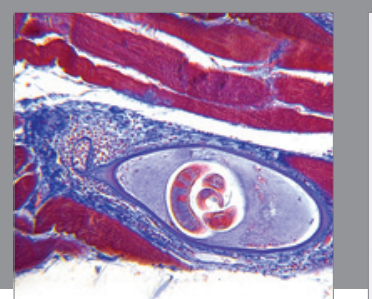

Gastroenterology Research and Practice

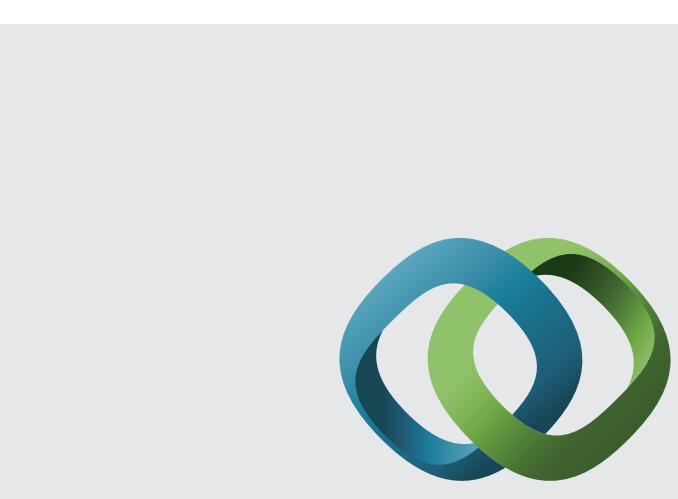

\section{Hindawi}

Submit your manuscripts at

http://www.hindawi.com
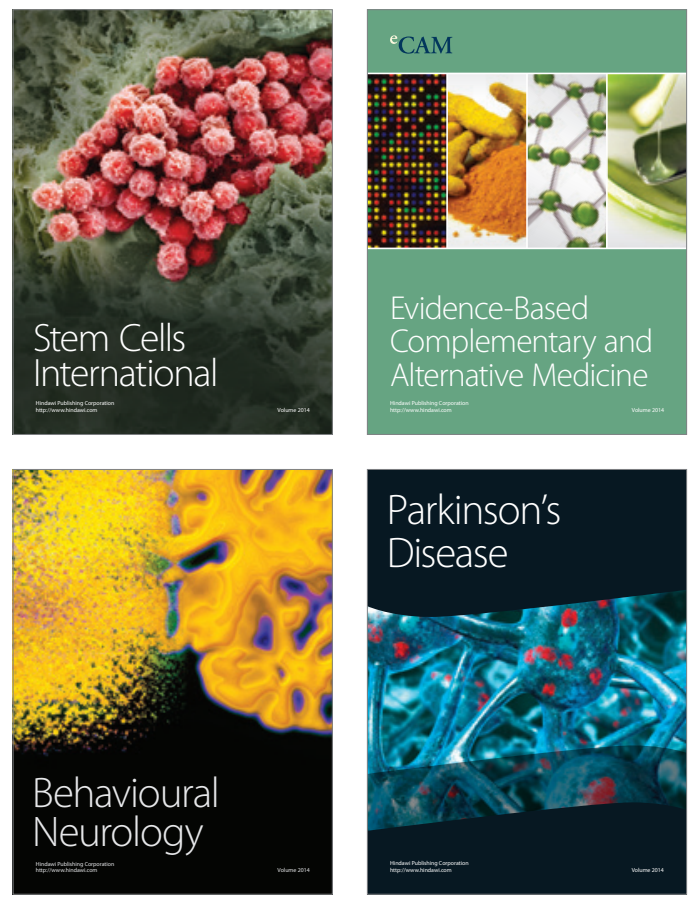
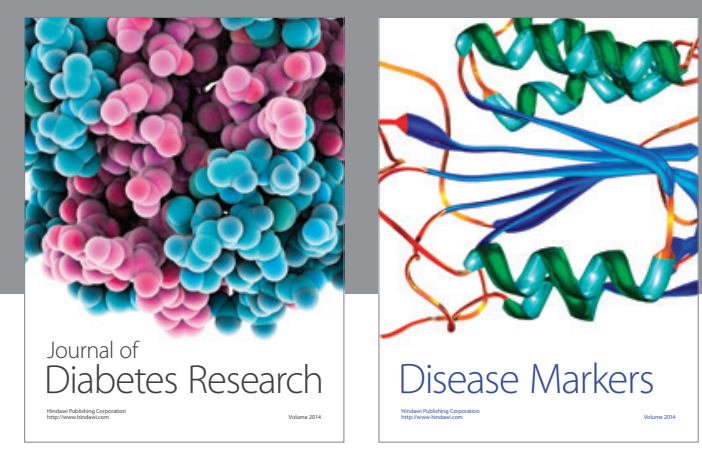

Disease Markers
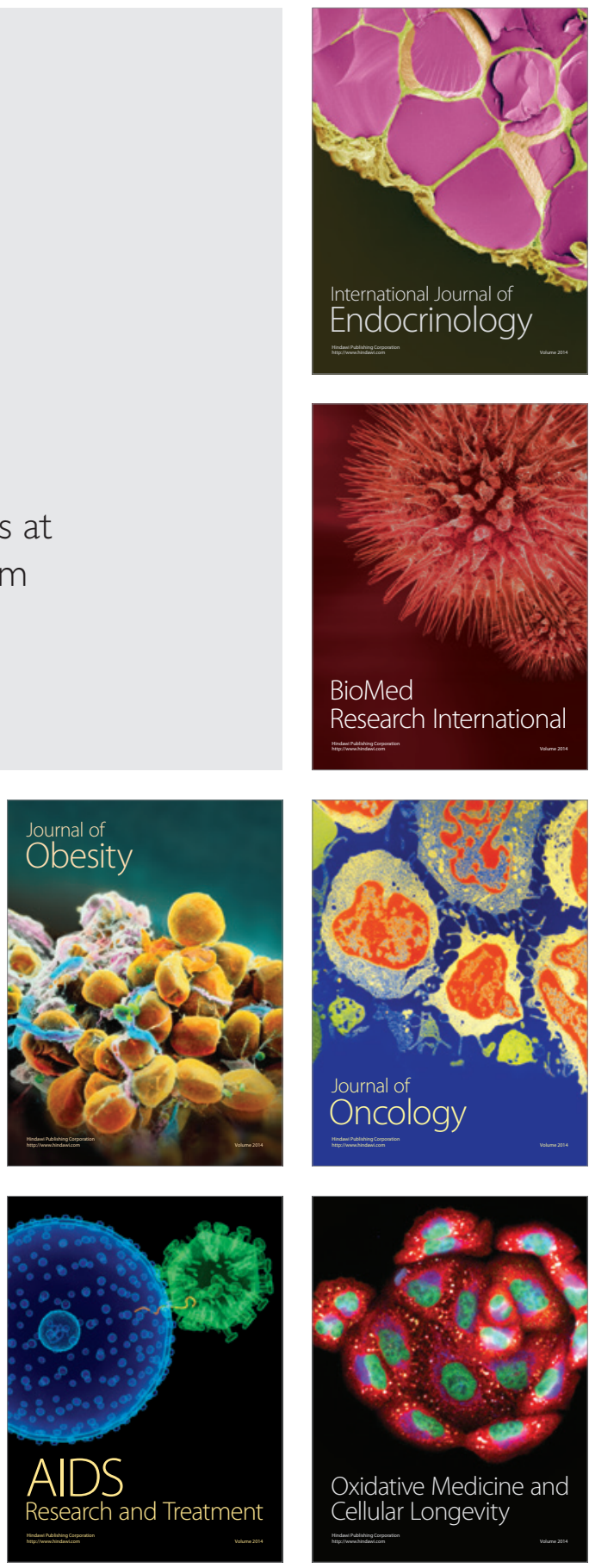